\title{
Elite Politics and the Fourth Generation of Chinese Leadership
}

\author{
ZHENG YONGNIAN \& LYE LIANG FOOK*
}

\begin{abstract}
The personnel reshuffle at the $16^{\text {th }}$ National Congress of the Chinese Communist Party is widely regarded as the first smooth and peaceful transition of power in the Party's history. Some China observers have even argued that China's political succession has been institutionalized. While this paper recognizes that the Congress may provide the most obvious manifestation of the institutionalization of political succession, this does not necessarily mean that the informal nature of politics is no longer important. Instead, the paper contends that Chinese political succession continues to be dictated by the rule of man although institutionalization may have conditioned such a process. Jiang Zemin has succeeded in securing a legacy for himself with his "Three Represents" theory and in putting his own men in key positions of the Party and government. All these present challenges to Hu Jintao, Jiang's successor. Although not new to politics, $H u$ would have to tread cautiously if he is to succeed in consolidating power.
\end{abstract}

\section{INTRODUCTION}

Although the $16^{\text {th }}$ Chinese Communist Party (CCP) Congress ended almost a year ago, the outcomes and implications of the Congress continue to grip the attention of China watchers, including government leaders and officials, academics and businessmen. One of the most significant outcomes of the Congress, convened in Beijing from November 8-14, 2002, was that it marked the first ever smooth and peaceful transition of power since the Party was formed more than 80 years ago. ${ }^{1}$

Neither Mao Zedong nor Deng Xiaoping, despite their impeccable revolutionary credentials, successfully transferred power to their chosen successors. Their appointed successors Lin Biao, Liu Shaoqi, Hu Yaobang and Zhao Ziyang all fell by the wayside. In contrast, Jiang, a technocrat whom detractors dismissed as no more than a mere seat-warmer in 1989, has presided over such an unprecedented transition. ${ }^{2}$ This is all the more significant as $\mathrm{Hu}$ was not even Jiang's chosen successor. In examining the political significance of the Congress, some China observers have argued that China's political succession has been institutionalized.

The term "institutionalization of political succession" has been a much debated topic among China scholars. Frederick C. Teiwes has argued that the postMao period saw an evolution towards "normal politics with Chinese characteristics"3; Tang Tsou has described it as "the process in which formal politics and formal relationships regularly prevail over informal politics and informal relationships"4; and, yet others such as Susan Shirk have argued for caution and observed that the

\footnotetext{
* Zheng Yongnian is Senior Research Fellow at the East Asian Institute, and Lye Liang Fook is Research Officer at the same institute. The authors are grateful to the two anonymous referees for their valuable comments on the paper.
}

(C) Journal of Chinese Political Science, vol. 8, nos. 1 \& 2, Fall 2003 
institutionalization of Chinese political system has been "retarded, uneven and reversible". 5 So far, no consensus has been reached on a definition of this term.

In this paper, the institutionalization of leadership succession refers to the apparent increasing trend of conducting politics in China through formal procedures including the legal stipulation that the President can only serve two terms in office, and the greater emphasis placed on institutions rather than persons in managing the affairs of the country. Formal procedures here also include established practices such as requiring top senior leaders who are beyond 70 years old to step down and allowing for "graceful" political exit as had characterized Qiao Shi's retirement in 1997.

On this basis, the paper examines the degree of institutionalization of China's political succession at the very top from two perspectives, i.e. the outcomes of the $16^{\text {th }}$ Party Congress, and the political background leading to the Congress and thereafter. Institutionalization, like elsewhere, is a process spanning several years and more so in China where traditionally the rule of man prevails. In China, the manifestation of such a process is most obvious from the key outcomes reached at the $16^{\text {th }}$ Party Congress. Equally important, if not more so, is to set in context the significance of China's political succession by reviewing the political developments prior to the Congress.

The paper is divided into three parts. Part I briefly examines the major political outcomes of the $16^{\text {th }}$ Party Congress; Part II sets these outcomes in the context of politics prior to the Congress; and Part III looks at the ensuing power succession in China which suggests that the institutionalization of political succession in China is far from straightforward. While China may appear to be heading in the direction of greater transparency and predictability with the greater acceptance of formal rules and the role of institutions, informal politics remain the dominant theme of leadership succession.

\section{KEY POLITICAL OUTCOMES}

\section{Changes in the Leadership Structure}

All six of the previous seven-member Politburo Standing Committee, other than $\mathrm{Hu}$, stepped down as they had reached or were beyond the mandatory retirement age limit of 70. As for Li Ruihuan, he was forced by Jiang to retire although he was only 68. Table 1 shows the present members of the Politburo and its Standing Committee.

The $16^{\text {th }}$ Party Congress witnessed the continued trend of electing younger and better-educated leaders. In the expanded Politburo Standing Committee, eight of its nine members are new. Within the Politburo, fifteen out of its sixteen members (excluding its Standing Committee) are new. Only $\mathrm{Wu} \mathrm{Yi} \mathrm{moved} \mathrm{up} \mathrm{from} \mathrm{an}$ alternate member in the last Politburo to become a full member in the present Politburo. The average age of all Politburo members is 60.6, compared with the average age of 63 for the $15^{\text {th }}$ Congress, 62 for the $14^{\text {th }}$, and 64 for the $13^{\text {th }}$ and 72 for the $12^{\text {th }}$. 
Table 1. The Politburo and Its Standing Committee at the 16th Party Congress (2002)

\begin{tabular}{|c|c|c|c|}
\hline \multirow{2}{*}{$\begin{array}{l}\text { Members of } \\
\text { Standing } \\
\text { Committee }\end{array}$} & Name & Age & Education \\
\hline & Hu Jintao & 60 & Qinghua University \\
\hline \multirow{8}{*}{$\begin{array}{l}\text { Average age: } \\
62.1\end{array}$} & Wu Bangguo* & 61 & Qinghua University \\
\hline & Wen Jiabao* & 60 & Beijing Geology Institute \\
\hline & Jia Qinglin* & 62 & Hebei Engrg. Institute \\
\hline & Zeng Qinghong* & 63 & Beijing Engrg. Institute \\
\hline & Huang $\mathrm{Ju}^{*}$ & 64 & Qinghua University \\
\hline & Wu Guanzheng* & 64 & Qinghua University \\
\hline & Li Changchun* & 58 & Ha'erbin Industrial University \\
\hline & Luo Gan* & 67 & Beijing Steel Institute \\
\hline \multirow{5}{*}{$\begin{array}{l}\text { Members of } \\
\text { Politburo } \\
\text { (excluding } \\
\text { Standing } \\
\text { Committee) }\end{array}$} & Wang Lequan* & 58 & Central Party School \\
\hline & Wang Zhaoguo* & 61 & Ha'erbin University \\
\hline & Hui Liangyu* & 58 & Jilin Provincial Party School \\
\hline & Liu Qi* & 60 & Beijing Steel Institute \\
\hline & Liu Yunshan* & 55 & Central Party School \\
\hline \multirow{11}{*}{$\begin{array}{l}\text { Average age: } \\
59.8\end{array}$} & $\mathrm{Wu} \mathrm{Yi}$ & 64 & Beijing Petroleum Institute \\
\hline & Zhang Lichang* & 64 & Beijing Economic Institute \\
\hline & Zhang Dejiang* & 56 & (North) Korea University \\
\hline & Chen Liangyu* & 56 & PLA Military Engineering School \\
\hline & Zhou Yongkang* & 60 & Beijing Petroleum Institute \\
\hline & Yu Zhengsheng* & 55 & Ha'erbin Military Engineering Institute \\
\hline & He Guoqiang* & 59 & Beijing Chemistry Engineering Institute \\
\hline & Guo Boxiong* & 60 & PLA Military School \\
\hline & Cao Gangchuan* & 67 & Soviet Union military school \\
\hline & Zeng Beiyan* & 64 & Qinghua University \\
\hline & Wang Gang* (alternate) & 60 & Jilin University \\
\hline
\end{tabular}

* Newly-recruited members

As shown in Table 1, all current Politburo members have at least college education and above. The trend towards a technocratic leadership has continued unabated. Like the last Politburo, the majority of the present Politburo members have engineering background. Within the Politburo Standing Committee, all members are engineers, in contrast to the last Politburo Standing Committee where $\mathrm{Li}$ Ruihuan and Li Lanqing were not from engineering background. Another 
important difference is that unlike Jiang Zemin, Li Peng, Wei Jianxing and Li Lanqing who had studied overseas such as in the then-Soviet Union, the current crop of Politburo Standing Committee members received their education in China. In other words, they have no overseas educational experience compared to their predecessors.

In the Central Committee, 180 of its 356 members or 50.6 per cent are new entrants. Such a scale of rejuvenation is large by recent standards. Table 2 shows the average age of the Central Committee member to be 55.4, compared with 56 for the $15^{\text {th }}$ Congress, 56 for the $14^{\text {th }}, 55$ for the $13^{\text {th }}$ and 62 for the $12^{\text {th }}$. As stated earlier, there is also a progressively younger crop of leaders in the Politburo and its Standing Committee.

Table 2 also shows that in terms of education, the percentage of Central Committee members having college education and above is 98.6, compared with 92, 84, 73 and 55 respectively, for the four preceding Congresses. It would appear from the above that promotion to the Central Committee and Politburo will increasingly be based on education and performance although an individual's personal relationships will continue to be important but would not be the sole deciding criterion.

Table 2. Changes in Average Age of the Top CCP Leadership ( 1982-2002)

\begin{tabular}{|c|c|c|c|c|}
\hline \multirow[b]{2}{*}{ Congress/Year } & \multicolumn{2}{|c|}{ Central Committee Members } & \multirow{2}{*}{$\begin{array}{l}\text { Politburo } \\
\text { Members }\end{array}$} & \multirow{2}{*}{$\begin{array}{l}\text { Politburo Standing } \\
\text { Committee Members }\end{array}$} \\
\hline & Age & $\begin{array}{l}\text { With college and } \\
\text { above education (\%) }\end{array}$ & & \\
\hline $12^{\text {th }}(1982)$ & 62 & 55.4 & 71.8 & 73.8 \\
\hline $13^{\text {th }}(1987)$ & 55.2 & 73.3 & 64 & 63.6 \\
\hline $14^{\text {th }}(1992)$ & 56.3 & 83.7 & 61.9 & 63.4 \\
\hline $15^{\text {th }}(1997)$ & 55.9 & 92.4 & 62.9 & 65.4 \\
\hline $16^{\text {th }}(2002)$ & 55.4 & 98.6 & 60.6 & 62.1 \\
\hline
\end{tabular}

\section{Distribution of Power}

Although Hu ranks the highest in the Politburo Standing Committee, he lacks factional support. At first glance, there is few among the Politburo Standing Committee members whom he can really count on for support. Wen Jiabao, elevated to Premier in March 2003, has traditionally been careful to shun factional politics, a reason that has contributed to his political longevity. Known as the "humpty dumpty" in China's political circles, Wen has outlasted three of his mentors namely $\mathrm{Hu}$ Yaobang, Zhao Ziyang and Jiang Zemin. Like Zhu Rongji, Wen is expected to focus his energy on tackling the serious challenges confronting the economy rather than engage in factional politicking. 
In contrast, Jiang, even though he has relinquished his senior party post, can count on six supporters among the nine members of the Politburo Standing Committee. They include Wu Bangguo, Jia Qinglin, Zeng Qinghong, Huang Ju, Wu Guanzheng and Li Changchun. ${ }^{6}$ Another factor in Jiang's favor is the disappearance of the Qiao Shi's faction in the Politburo Standing Committee.

At the $199715^{\text {th }}$ Party Congress, although Jiang succeeded in forcing Qiao Shi to step down from the Politburo, he still had to contend with Qiao's supporters, Wei Jianxing and Tian Jiyun. Now, without Wei and Tian at the $16^{\text {th }}$ Party Congress, Jiang's faction has even greater room to maneuver. Given the influence Jiang still wields, it is not surprising that the media has portrayed $\mathrm{Hu}$ as a hapless leader under Jiang's shadow. This was especially so in the immediate aftermath of the Congress with headlines such as "Hu's in Charge?", "Hu pledges to confer with Jiang on issues," "The Shanghai faction consolidates its grip on power," and "Is Hu going to be lame-duck leader?"10

A caveat is necessary here. Jiang's faction is not monolithic; sub-factions exist among his own men, making it difficult for the faction to work together as a unit. There are essentially two groups. The first, the Shanghai Gang, comprises Wu Bangguo (Chairman of the National People's Congress), Zeng Qinghong (Vice President) and Huang Ju (Vice Premier). The second group, Jiang's loyalists, comprises Jia Qinglin (Chairman of the Chinese People's Political Consultative Committee), Li Changchun (Member of the Politburo Standing Committee in charge of ideology and propaganda) and Wu Guanzheng (Member of the Politburo Standing Committee and Secretary of Central Commission for Discipline Inspection).

Even within each of the two groups, there are sub-factions. For instance, Huang $\mathrm{Ju}$ is reputed to be calculative and may not be able to get along with Zeng Qinghong. Also, as Jiang's men are holding key positions in different party and government organizations, they may ultimately have to be more accountable to the institutions that they represent. Furthermore, one cannot rule out the possibility that one or two of Jiang's men may try to get close to $\mathrm{Hu}$ to ensure their long-term political career and survival. Such intrigue will intensify as Jiang gets more advanced in years.

\section{Greater Provincial and "Taizidang" Representation}

An interesting outcome of the $16^{\text {th }}$ Party Congress is the greater representation of the provinces in the Politburo. In the Politburo Standing Committee, there is now a relative balance of representatives from Beijing and the provinces. Table 3 shows that four out of the nine members, namely Jia Qinglin (Beijing), Huang Ju (Shanghai), Wu Guanzheng (Shangdong) and Li Changchun (Guangdong) are from the provinces and cities. And looking at the Politburo as a whole, the balance is in favor of provincial representation. Thirteen out of the twenty-four Politburo members or 54.2 per cent are from the provinces. Such a heavy representation of the provinces in the highest leadership has never taken place in previous Party Congresses where most leaders came from central bureaucracies. 
Table 3. Growing Provincial Representation

\begin{tabular}{|l|l|l|}
\hline & Name & Local Base* \\
\hline Politburo Standing Committee & Jia Qinglin & Beijing \\
& Huang Ju & Shanghai \\
& Wu Guanzheng & Shandong \\
& Li Changchun & Guangdong \\
\hline Politburo & Wang Lequan & Xinjiang \\
& Hui Liangyu & Jiangsu \\
& Liu Qi & Beijing \\
& Zhang Lichang & Tianjin \\
& Zhang Dejiang & Zhejiang \\
& Chen Liangyu & Shanghai \\
& Zhou Yongkang & Sichuan \\
& Yu Zhengsheng & Hubei \\
& He Guoqiang & Chongqing \\
\hline
\end{tabular}

* Local base at the time of the 16th Party Congress. There have been some changes since then. For instance, Hui Liangyu is now the Vice Premier; Zhang Dejiang the Party Secretary of Guangdong; Zhou Yongkang the State Councilor and Minister of Public Security; and, He Guoqiang the Head of the Party's Central Organization Department.

Table 4 shows that among the thirteen provincial leaders, the power is skewed towards the coastal provinces - Beijing, Shanghai, Shandong, Guangdong, Jiangsu, Tianjin and Zhejiang. This is due to the Party's recognition of the important role of the coastal provinces in China's economic development, and its willingness to let these provinces have a greater say in its highest decision-making body.

There are only four inland provinces represented in the Politburo - Xinjiang, Sichuan, Hubei and Chongqing. Although the representation of inland provinces is more than the previous Politburo, it is more symbolic than substantive. It suggests that the leadership wants to show its attention to the development of the inland provinces. The inclusion of Xinjiang in the Politburo for the first time indicates the Party's commitment to not only bringing economic prosperity to the region but also to containing separatist movements, especially in an age of global anti-terrorism.

Table 4. Representation of Coastal and Inland Provinces

\begin{tabular}{|l|l|l|}
\hline & Name & Province \\
\hline Coastal & Jia Qinglin & Beijing \\
& Huang Ju & Shanghai \\
& Wu Guanzheng & Shandong \\
& Li Changchun & Guangdong \\
& Hui Liangyu & Jiangsu \\
& Liu Qi & Beijing \\
& Zhang Lichang & Tianjin \\
& Zhang Dejiang & Zhejiang \\
& Chen Liangyu & Shanghai \\
\hline Inland & Wang Lequan & Xinjiang \\
& Zhou Yongkang & Sichuan \\
& Yu Zhengsheng & Hubei \\
& He Guoqiang & Chongqing \\
\hline
\end{tabular}


Yet another significant outcome of the $16^{\text {th }}$ Party Congress is the emergence of so-called "taizidang" or offspring of party elders. This group had been deliberately sidelined for at least the past 10 years. Deng Xiaoping had denied them access to power for fear of evoking ill-will among the people. ${ }^{11}$ Under Deng, memories of the 1989 Tiananmen incident where students called on the Party to rid itself of political favoritism and nepotism were still vivid. At that time, being associated with a taizidang was considered to be more of a political liability than an asset.

In contrast, the $16^{\text {th }}$ Party Congress and its aftermath saw much greater prominence accorded to taizidang in the power hierarchy. Table 5 shows several taizidang who have risen to prominence recently. Foremost among them is Zeng Qinghong, member of the Politburo Standing Committee and son of Zeng Shan, the former Minister of Internal Affairs. Others include Yu Zhengsheng (Party Secretary of Hubei), Xi Jinping (Party Secretary of Zhejiang), Bai Keming (Party Secretary of Hebei), Bo Xilai (Governor of Liaoning) and Hong Hu (Governor of Jilin) and Wang Qishan (Acting Mayor of Beijing).

Worth elaborating here is Wang Qishan, the current Beijing Mayor appointed in April 2003 to replace Meng Xuenong who had bungled in his attempt to handle the SARS outbreak. Prior to this, Wang was Party Secretary of Hainan for a few months. Wang is dynamic and decisive, and is a good public speaker. Barring any unforeseen circumstances, Wang is expected to assume a higher position in the Party and government. ${ }^{12}$ Also worth mentioning is the appointment of Bai Keming as Chairman of the Standing Committee of Hebei Provincial People's Congress in January 2003 who is concurrently Hebei's Party Secretary. Bai replaces Cheng Weigao who was expelled from the party for violating Party discipline. ${ }^{13}$ Cheng had allegedly engaged in corruption deals involving his family and two secretaries. Bai Keming's appointment is significant because it demonstrates the renewed trust bestowed by the top leadership on a taizidang to curb corruption. Such an outcome would not have been possible in the late 1980s and for most part of the 1990s.

Table 5. The Rise of Taizidang

\begin{tabular}{|l|l|l|}
\hline Name & Present Position & Family Background \\
\hline Zeng Qinghong & $\begin{array}{l}\text { Vice President and Politburo } \\
\text { Standing Committee Member }\end{array}$ & $\begin{array}{l}\text { Son of Zeng Shan, Minister of Internal } \\
\text { Affairs }\end{array}$ \\
\hline Yu Zhengsheng & Party Secretary, Hubei & Son of Huang Jin, Mayor of Tianjin \\
\hline Xi Jinping & Party Secretary, Zhejiang & Son of Xi Zhongxiong, PLA General \\
\hline Bai Keming & Party Secretary, Hebei & $\begin{array}{l}\text { Son of Bai Jian, Deputy Minister of First } \\
\text { Mechanical Industry }\end{array}$ \\
\hline Wang Qishan & $\begin{array}{l}\text { Acting Mayor, Beijing; former } \\
\text { Party Secretary, Hainan }\end{array}$ & $\begin{array}{l}\text { Son-in-law of Yao Yilin, Politburo } \\
\text { Standing Committee member }\end{array}$ \\
\hline Bo Xilai & Governor, Liaoning & Son of Bo Yibo, Politburo member \\
\hline Hong Hu & Governor, Jilin & Son of Hong Xiuzhi, PLA general \\
\hline
\end{tabular}

The emergence of taizidang can be attributed to the following three reasons: First, they are considered by the Party to be reliable and loyal, particularly at a time 
when the Party faces many daunting challenges. Second, a number of taizidang have proven themselves to be capable and deserving of the posts they currently occupy. In other words, meritocracy also applies to the taizidang. Third, unlike the Deng period, when it was politically sensitive to promoting the sons of party elders who were still alive, there is less need for such caution now as many of these elders are no longer around.

\section{Party Still Controls the Gun}

The $16^{\text {th }}$ Party Congress once again reaffirmed that the Party remains in control of the military. In line with the tradition set at the $15^{\text {th }}$ Party Congress, no military man is appointed to the Politburo Standing Committee. Also, in accordance with previous practices, two representatives of the military, Guo Boxiong and Cao Gangchuan, are appointed to the Politburo. Table 6 shows that Guo Boxiong and Cao Gangchuan are also concurrently Vice Chairmen of the Central Military Commission (CMC).

Jiang, a civilian and a non-Central Committee member, remains in control of the PLA as CMC Chairman. Jiang appears to be following in the footsteps of Deng, who was CMC Chairman from 1987 to 1989 even though he was not a Central Committee member. It is, however, unclear how long Jiang intends to hold on to this position. What appears clear is that Jiang does not intend to take a back seat anytime soon.

Table 6. The Central Military Commission

\begin{tabular}{|l|l|l|}
\hline & Previous Members & Present Members \\
\hline Chairman & Jiang Zemin (1926) & Jiang Zemin (1926) \\
\hline Vice Chairmen & Hu Jintao (1942) & Hu Jintao (1942) \\
& Zhang Wannian (1928) & Guo Boxiong (1942) \\
& Chi Haotian (1929) & Cangchuan (1935) \\
\hline CMC Members & Fu Quanyou (1930) & Liang Gaunglie (1940) \\
& Wang Ke (1931) & Liao Xilong (1940) \\
& Yu Yongbo (1931) & Li Jinai (1942) \\
& Wang Ruilin (1929) & \\
& Guo Boxiong (1942) & \\
& Xu Caihuo (1943) & \\
& Cao Gangchuan (1935) & \\
\hline
\end{tabular}

Within the CMC, other than Jiang and $\mathrm{Hu}$, six out of its nine generals have stepped down. There are three significant points about the CMC set-up. First, with the exception of Jiang Zemin (76) and Cao Gangchuan (67), the rest of the members are around 60 years of age. This places them among the fourth generation of leaders and contemporaries to $\mathrm{Hu}$. Second, only three of the six vacated military spots are replaced. They are by Liang Guanglie (62, Chief, PLA General Staff), Liao Xilong (62, Director, General Logistics Department) and Li Jinai (60, Chief, General Armaments Department). The main reason for not filling all the vacated positions is perhaps to leave room for Hu to make his own appointments in the future. 
Third, like the Politburo Standing Committee, some sort of factional balance has been achieved in the CMC. The two retired generals, Zhang Wannian, former Vice Chairman of $\mathrm{CMC}$, and $\mathrm{Fu}$ Quanyou, former Chief of General Staff, have ensured that their own men assumed positions in the CMC.

Table 7 shows the background of the CMC members. Zhang Wannian's supporters in the CMC include Guo Boxiong (served under Zhang as Deputy Commander, Beijing Military Region), Li Jinai (served under Zhang when he was Commander, Jinan Military Region) and Xu Caihou (who takes over from Zhang as the key go-between for the Party and the PLA nerve centers). Fu Quanyou's supporters in the CMC include Liao Xilong who fought in the war against Vietnam in 1979, and together with $\mathrm{Fu}$, helped to enforce martial law when it was declared in Lhasa in March 1989. Interestingly, that was also the time when $\mathrm{Hu}$ was Party Secretary of Tibet. Liao Xilong is reported to be Hu's ally.

Table 7. Background of CMC Members of the $16^{\text {th }}$ Party Congress

\begin{tabular}{|l|l|}
\hline Name & Background \\
\hline Jiang Zemin & Chairman, CMC \\
\hline Hu Jintao & Vice Chairman, CMC \\
\hline Guo Boxiong & $\begin{array}{l}\text { Executive Deputy Chief, General Staff Headquarters; Commander, } \\
\text { Lanzhou Military Region and Deputy Commander, Beijing Military } \\
\text { Region }\end{array}$ \\
\hline Cao Gangchuan & Director, General Armament Dept.; Deputy Commander, Vietnam War \\
\hline Xu Caihou & $\begin{array}{l}\text { Executive Deputy Director, General Political Dept.; Political Commissar, } \\
\text { Jinan Military Region }\end{array}$ \\
\hline Liang Guanglie & $\begin{array}{l}\text { Commander, Nanjing Military Region. Also served in Jinan Military } \\
\text { Region and Beijing Military Region }\end{array}$ \\
\hline Liao Xilong & Commander, Chengdu Military Region \\
\hline Li Jinai & $\begin{array}{l}\text { Political Commissar, General Armament Dept.; Political Commissar, } \\
\text { Commission of Science, Technology \& Industry for National Defense }\end{array}$ \\
\hline
\end{tabular}

The question that arises is whether $\mathrm{Hu}$ can command the military as effectively as Jiang. This is crucial if $\mathrm{Hu}$ is to succeed in consolidating power. To some extent, Hu can hope to build on Jiang's success in institutionalizing partymilitary relations. Some of Jiang's initiatives included creating a more professional PLA; promoting generals to key positions in the military; promulgating the National Defense Law of 1997 that established the Party's legal control over the military; delinking the military from business; and, increasing the military's defense spending at double-digit rates every year since 1989. Other than institutional means, and perhaps more important, Hu will have to win over the trust and confidence of the PLA. This will take time.

\section{POLITICAL PROCESS}

\section{Run-up to the 16th Party Congress}

Judging from the key outcomes of the $16^{\text {th }}$ Party Congress outlined above, it would appear that some positive steps have been made in the direction of 
institutionalizing political succession in China. Indeed, political succession has moved beyond the stage of the law of the jungle under the days of Mao Zedong where anything can be resorted to, including even political assassinations, in order to remove your political opponents.

But the degree of institutionalization of political succession should be set in context. For one, the conduct of politics in China is still very much people-driven, where who you are, where you stand in the power hierarchy and who you know still matters a great deal. The rule of man is very much a predominant factor in Chinese politics. Also, the prevailing communist political culture, where the Party retains the final say on important decisions affecting the country including leadership succession, virtually places a limit on the institutionalization of political succession in China.

In the absence of a clear and established way of dealing with leadership succession, politics and political patronage become most important. An examination of what happened prior to $16^{\text {th }}$ Party Congress will illustrate the intense power struggle among key party leaders behind what has been generally regarded as a smooth political succession.

\section{Tightening of the Political Atmosphere}

Like presidential elections in democratic states such as the US, the fiveyearly Party Congress is the most important political event in Chinese politics. But unlike politicians in democratic settings who compete for popular votes based on established rules and norms, Chinese party leaders do not operate within such clear parameters. In their case, the emphasis is on intense political infighting and maneuvering to either ensure their political survival or aggregate greater power onto themselves. At a higher level, a key motivation of these party leaders is to ensure the continued domination of Chinese politics by the CCP. The $16^{\text {th }}$ Party Congress was no exception. It was the singular event that dominated China's political landscape in 2002. Virtually all work on the political front for the entire year was related to or geared towards this major event.

In particular, a premium was placed by the Party and government on setting the right tone for the Congress. Maintaining nationwide stability and ensuring minimal disruption to preparations for the Congress assumed urgency in light of a spate of workers' unrest in various parts of China including Heilongjiang, Liaoning, Jilin, Gansu, Guizhou and even Beijing. Instead of new major initiatives, the Party and government concentrated on fine-tuning existing policies, such as sustaining high economic growth, or focusing on issues of concern to the people, such as tackling unemployment and reducing the burden on farmers. ${ }^{14}$

The Party's propaganda machinery went into overdrive extolling the achievements of the Party since the last Congress and in particular Jiang's contributions. A book entitled "Jiang Zemin on Socialism with Chinese Characteristics" containing important reports, speeches, articles, letters and written instructions by Jiang over a thirteen-year period was published. Jiang's pictures appeared alongside Mao Zedong and Deng Xiaoping in public. The People's Daily (i.e. Renmin Ribao) highlighted the overwhelming nationwide support for the Congress. Also, news announcing the successful damming of the Three Gorges Dam 
was deliberately timed a day before the start of the Congress to drum up the celebrative mood. $^{15}$

Party discipline was tightened. Wu Bangguo exhorted cadres not to start or spread political rumours or say anything to tarnish the image of the Party or country. He further called on cadres not to publicly contradict the policies or strategies decided by the Party but to channel their opinions internally. ${ }^{16}$ Luo Gan separately called on the Party and government to be vigilant against disruptive elements such as terrorism, ethnic separatism, religious extremism, internal and external threats, and the Falungong movement. ${ }^{17}$

A tighter rein was simultaneously exerted by the Party and government on the print and electronics media. In June 2002, the Party's Central Propaganda Department issued a directive listing 32 areas where the media should either exercise extreme caution when reporting (e.g. impact of WTO entry on various economic sectors in China) or refrain from doing (e.g. sensationalization of news). ${ }^{18}$ In an unprecedented move, eight government bodies ${ }^{19}$ joined hands to launch a nationwide campaign to curb the spread of undesirable information on the domestic Internet network which could affect national security and social stability. ${ }^{20}$

\section{Jiang's Political Maneuvering}

The intense jostling for power among the top leadership in the lead-up to the Congress showed that politics in China is still very much people-driven. In the Chinese context, one would do well to draw a distinction between political succession and power succession. On the one hand, political succession, taken to mean the handing over of the reins of power to a younger generation of leaders, is widely regarded to have been completed at the $16^{\text {th }}$ Party Congress, if not at the $10^{\text {th }}$ National People's Congress in March 2003. On the other, power succession, defined as the on-going attempt by $\mathrm{Hu}$ to consolidate power, has only just begun. To a large extent, the focus in the run-up to the $16^{\text {th }}$ Party Congress and at the Congress itself was on extending Jiang's political influence rather than the handing over of power to $\mathrm{Hu}$.

At the very top, Zhu Rongji was the only leader who had indicated early that he would be relinquishing his senior party post at the Congress and giving up his premiership in March 2003. In contrast, neither Jiang nor Li Ruihuan has ever stated their intention in such unequivocal terms.

As mentioned above, Li Ruihuan at 68 was below the mandatory retirement age limit of 70 for Politburo members and technically, could still remain on the Politburo Standing Committee. But he was forced to retire by Jiang to avoid the situation where he would be the most senior and experienced member of the Politburo Standing Committee with whom $\mathrm{Hu}$ would have to work closely with when Jiang, Li Peng and Zhu Rongji simultaneously stepped down from the Politburo. This would have complicated Jiang's efforts to place his own men in the top echelons of the Party.

As for Jiang, speculation was rife then that he would either fully retire or surrender only his party and government positions while retaining the top military post. Up till the eve of the Congress it was not altogether clear what the final 
outcome would be. Jiang kept his future plans close to his chest and used it as a bargaining chip to secure positions of influence for himself and his supporters. Incessant calls by Jiang's supporters urging him to stay on or exhorting others to rally under his leadership added to the uncertainty. In a speech at the Guangdong Party School in July 2002, Li Changchun, Party Secretary, urged Guangdong party cadres at all levels to keep in line with the leadership, with Jiang at the core. ${ }^{21}$

The PLA, in particular, was one of Jiang's ardent advocates. On separate occasions in January and June 2002, General Fu Quanyou, former Chief of General Staff, called on the Chinese military to obey the core of the Party and military leadership led by Jiang "no matter when and under whatever circumstances". ${ }^{22}$ General Chi Haotian, Defence Minister, echoed the same message in June 2002. ${ }^{23}$ These statements were strong pledges of allegiance to a person, not to an office. Jiang himself fueled speculation that he intended to retain his military authority after the 16th Party Congress when he made the rather unusual move of promoting seven PLA officers to the rank of full general in June 2002.

The Beidaihe meeting in July 2002, where China's top leaders gather for their annual retreat, failed to finalize the leadership line-up for the $16^{\text {th }}$ Party Congress. The subsequent announcement that the Congress would be held in November 2002, rather than September as earlier speculated, fueled talks of intense wrangling among the top leaders. Opposition to Jiang's staying on came from two main quarters within the Party. First, Li Ruihuan had apparently offered to step down from the Politburo Standing Committee, although not required to do so, to exert pressure on Jiang. Second, discordant notes were sounded by Wei Jianxing, from Qiao Shi's faction, decrying Jiang's unwillingness to relinquish power. Jiang was portrayed as reneging on his pledge to make room for a new generation of leaders when he forced Qiao Shi to retire in 1997.

To counter these challenges, Jiang mounted an ideological offensive by enunciating the "New Three Talks" with its stresses on "Solidarity, the Big Picture and Stability". Although the "New Three Talks" was first mentioned in Jiang's May $31^{\text {st }}, 2002$ speech, it only gained greater prominence when the People's Daily gave front page coverage in an article on this topic. ${ }^{24}$ The article appeared to be directed at containing unwarranted rumours originating from party cadres on personnel arrangements at the highest level as well as the unhealthy jostling for power among them. This was Jiang's message to his political supporters and foes alike to rally to the Party and nation's cause and not do anything to upset the leadership transition as orchestrated by Jiang.

Jiang also moved quickly to mobilize political support from the provinces and central ministries. On the eve of the Congress, a fresh round of personnel reshuffling took place. Most significantly, the majority of those reshuffled were Jiang's men. In October 2002, Zeng Qinghong relinquished his post as Head of the Party's Organization Department, indicating that he would finally be elevated to the Politburo Standing Committee, a position which had eluded him for years. ${ }^{25} \mathrm{He}$ Guoqiang, Chongqing Party Secretary, replaced Zeng as Head of the Organization Department. Also, Liu Yunshan was appointed Head of the Central Propaganda Department. ${ }^{26}$ Around the same time, Jia Qinglin, Beijing Party Secretary, and 
Huang Ju, Shanghai Party Secretary, were moved to Party central. ${ }^{27}$ All five of them subsequently either became members of the Politburo or its Standing Committee.

\section{Jiang's Legacy}

Apart from positioning his own men to take up positions in the top leadership, Jiang also mounted a concerted effort to secure a legacy for himself on the ideological front. In particular, meticulous preparation went into Jiang's political report to the $16^{\text {th }}$ Party Congress with Jiang playing an active role in the process.

The Politburo Standing Committee decided to form the drafting committee of the political report in October 2001 chaired by $\mathrm{Hu}$ and which included Zeng Qinghong and Wen Jiabao. Teng Wensheng, head of the Party's Policy Research Office and Jiang's ally, was responsible for the actual drafting. The drafting committee was tasked to produce a report that would guide China to further the goal of building socialism with Chinese characteristics. ${ }^{28}$

Even though $\mathrm{Hu}$ was the Chairman of the drafting committee, Jiang closely supervised its work and intervened to ensure that it was on the right track. In a meeting with the drafting committee in January 2002, Jiang set the theme of the political report, which is to hold high the banner of Deng Xiaoping Theory, fully imbibe the thinking behind the "Three Represents" theory and construct a full fledged xiaokang shehui. Following this meeting, the drafting committee came up with the framework of the report and submitted it first to Jiang and then the Politburo Standing Committee for approval in February 2002. After several revisions, a draft of the report was ready in May 2002 which was again submitted to the Politburo Standing Committee for deliberation.

Jiang's May $31^{\text {st }}, 2002$ speech at the Central Party School, which traditionally is a platform for important pronouncements, gave the first public indication of the key elements that would be included in the political report. ${ }^{29}$ Jiang elaborated on the theme he stated in January 2002 and indicated that there was an emerging consensus that the admission of capitalist and private entrepreneurs was necessary for the Party's survival.

Not surprisingly, $\mathrm{Hu}$ was one of the staunchest supporters of Jiang's "Three Represents" theory. In July 2002, Hu unveiled new criteria for the selection and naming of party and government leaders. According to $\mathrm{Hu}$, cadres who embraced the important ideology of the "Three Represents" would be promoted. ${ }^{30}$ In an address at the Central Party School in September 2002, Hu extolled the "Three Represents" theory and called on party officials to back Jiang's political vision. ${ }^{31}$

There were, however, dissenting voices from pro-reform liberals and hardline communists criticizing Jiang's record although they were not serious enough to upset his plans. In a scathing attack on Jiang's "Three Represents" theory, Bao Tong, a former aide to purged party leader Zhao Ziyang and a de facto spokesman for liberals in China's political elite, asserted that the Party has abandoned the workers and peasants and become an authoritarian Party representing the rich and powerful. Rather than heralding the onset of democracy with the theory, Bao Tong contends that the Party is on the demise. ${ }^{32}$ Aside from Bao Tong, two letters written by conservative critics accused Jiang of abandoning the ideals of the Party by 
welcoming capitalists into its ranks. The organizer of one of the letters is believed to have ties with party elder Song Ping, known to be critical of Jiang. ${ }^{33}$

Despite all kinds of opposition, Jiang managed to include the "Three Represents" theory into the Party Constitution. This marks the culmination of years of efforts by Jiang to widen the social base of the Party by admitting capitalists as well as to ensure that the theory stays relevant. The preamble of the Party Constitution was also changed to reflect the Party as the vanguard not only of the working class, but also of the Chinese nation and Chinese people. This is a significant move by the Party to distance itself from any distinct social class and move towards a political entity that represents and coordinates the interests of various social classes.

Central to Jiang's vision to transform the whole of China is the concept of xiaokang shehui (comfortable society), which was the title of his political report to the $16^{\text {th }}$ Party Congress. The goal is to lay a firm foundation for achieving full-scale modernization by 2050. According to Jiang, China has already accomplished the first of two steps towards modernization set by Deng twenty years ago. ${ }^{34}$ Building on previous successes, Jiang has set the target of quadrupling China's GDP by 2020 with 2000 as base year. ${ }^{35}$

The vision to transform the entire country into a xiaokang shehui has significant economic implications. It reflects a need to change the pattern of China's economic growth. The emphasis, hitherto, has largely been on unbridled economic growth with wealth concentrated in the coastal provinces and cities while pockets of poverty remain scattered around the country, especially in the inland provinces and rural areas. Jiang's vision aims to address this lopsided development by redistributing wealth to a larger proportion of the population. This does not imply that China is turning its back on the market economy but rather that increased attention will be placed on re-distributing wealth through growth and stepping up economic development in the backward hinterland. This is a gradual and long-term strategy.

Apart from its economic implications, the term xiaokang shehui is politically significant for two reasons. First, in ideological terms, it is not only a deliberate rejection of the "middle class" concept used by the West but is also a denouncement of the Western notion of liberal democracy. In the West, the development of the middle class is inextricably linked to the development of democracy in these countries. Although detractors may argue that the term xiaokang shehui is none other than the communist jargon for the middle class, in reality, the significance is more than putting old wine into a new bottle. The Party is telling the whole country and the rest of the world that it wants to decide its own development path and will not be dictated to by outsiders. It is thus not without coincidence that in the same political report, Jiang categorically rejected the idea of China developing along the path of western liberal democracy.

Second, xiaokang shehui is not only intellectually appealing to the Chinese people, many of whom still yearn for a better life, but also politically correct because it propounds the notion that everybody could become well-off together. A comfortable society has some egalitarian notion that makes it readily acceptable to virtually all strata of society. 
In any case, the $16^{\text {th }}$ Party Congress has enabled Jiang to score a personal victory and seal his legacy by having the "Three Represents" theory included in the Party Constitution. The theory has entered the pantheon of Chinese revolutionary thought, sharing a status on par with Marxism-Leninism, Mao Zedong Thought and Deng Xiaoping Theory.

\section{CONTINUED POLITICAL UNCERTAINTIES}

\section{Ensuing Power Succession}

While a fresh and younger team under Hu's leadership is now at the helm, Jiang still wields influence on the conduct of politics in the country. Although $\mathrm{Hu}$ is the highest office bearer in the Party, it is not altogether clear whether he has the final say on important issues that affect the Party and country. Most glaringly, $\mathrm{Hu}$ has yet to be referred to as the "core" of the $4^{\text {th }}$ generation leadership. Also, Jiang is still active on the political stage in his capacity as Chairman of the CMC.

The Chinese military, for one, continues to pledge allegiance to Jiang. In the December 2002 issue of the Party's magazine, Qiushi, Lieutenant General Zhu Qi, a PLA officer in charge of the security of Beijing, said that the retention of Jiang in the top military post was "an important political choice made by the Party". 36

Jiang himself does not appear content to take a back seat. At the height of the Severe Acute Respiratory Syndrome (SARS) outbreak, Jiang signed an order in April 2003 as Chairman of the CMC to mobilize over 1,000 military doctors to staff the Xiaotangshan Hospital specially built in the outskirts of Beijing to deal with SARS patients. ${ }^{37}$ In May 2003, it was again Jiang who issued a condolence message to the families and relatives of the 70 officers and soldiers who perished when the Chinese Ming-class submarine they were on encountered a mechanical failure while on a regular training exercise. ${ }^{38}$ Also, Jiang continues to receive front-page coverage in the national dailies either at important functions or when he receives calls by foreign dignitaries in his capacity as Chairman of the CMC. ${ }^{39}$

Uncertainty also prevails over the kind of working relationship that will unfold among the triumvirate of Hu Jintao, Zeng Qinghong and Wen Jiabao although they appear to work well together. ${ }^{40}$ Most noticeably, Hu and Wen have made a conscious effort to distinguish their leadership style from that of their predecessors by focusing more on the masses and less privileged. Hu's first domestic tour after being elected as General Secretary was to Xibaipo, the Party's legendary headquarters in northern Hebei province. ${ }^{41}$ The intended message was that the Party would not forget its origin, that it was a Party founded to champion the interests of the suffering masses.

Wen, even before his appointment as Premier, had stressed the importance of accelerating agriculture and rural reform to raise the living standards of farmers and reduce their financial burdens at a Central Conference on Work in Rural Areas in January 2003. ${ }^{42}$ Echoing the views of the top leadership, Li Changchun, a member of the Politburo Standing Committee in-charge-of ideology and propaganda, as well as Jiang's erstwhile ally, had on a number of occasions this year called on party organs 
and officials working in the media industry to stay in close touch with the people and pay more attention to the issues that affect their lives. ${ }^{43}$

As for Zeng Qinghong, he is keeping a low profile and appears to be supportive of the Hu-Wen leadership. Most recently, Zeng had rallied under the HuWen leadership in their efforts to contain the SARS outbreak. ${ }^{44}$ With his mentor Jiang expected to be on the way out in a few years, Zeng would have realized that the best way to safeguard his political future is to build on his relationship with $\mathrm{Hu}$ and Wen. But it is unknown to what extent Zeng will be willing to defer to Hu in the long haul despite his public profession of support for $\mathrm{Hu}$.

The SARS outbreak in China and efforts to contain it provide some indication of the continued jostling for power between $\mathrm{Hu}$ and Jiang's factions. Worth highlighting here is the simultaneous sacking of Health Minister Zhang Wenkang and Beijing Mayor Meng Xuenong in April 2003. ${ }^{45}$ Zhang was regarded as belonging to Jiang's camp, while Meng was perceived to be Hu's protégé. While the sacking of Zhang was expected because of his blatant misinformation on the extent of the SARS outbreak and his failure to institute effective measures to prevent its spread, Meng's removal caught some China observers by surprise. This was all the more so when Meng was only appointed Beijing Mayor only three months ago, in January $2003 .{ }^{46}$

There is a perception that Meng Xuenong was made a sacrificial lamb by $\mathrm{Hu}$ to make it politically palatable for Jiang and his supporters to accept the political demise of Zhang Wenkang. ${ }^{47}$ Most significantly, the removal of two senior government officials was Hu's strategy of confining the political fallout for the mishandling of the SARS situation to the government bureaucracy so as to protect the interests of the Party. It is worthwhile to note that Beijing's Party Secretary and Politburo member Liu Qi, another Jiang ally, was let off with a public apology and remains in his current position. If he had also been removed, it would most certainly have elicited a backlash from Jiang's camp and would have weakened Hu's efforts at consolidating power.

Most interestingly, a week after the sacking of Zhang Wenkang and Meng Xuenong, Hu chaired a regular Politburo meeting to discuss the launching of a new round of study of Jiang's "Three Represents" theory. ${ }^{48}$ But why did Hu hold a seemingly unrelated meeting at the height of the SARS outbreak? How could the "Three Represents" theory provide an effective guide to the party leadership to combat SARS? At first glance, it is hard to see any correlation between the two. But seen from the political perspective, Hu's gesture is of some significance. Hu was making use of the "Three Represents" theory to reach out to Jiang's faction and to allay any concern that a political witch-hunt was in the offing. Hu wanted to show that he was for continuity and was willing to work with Jiang's faction to combat SARS. $^{49}$

In fact, there was a closing of party ranks to deal with the spread of SARS. Major figures in Jiang's faction including Wu Bangguo, ${ }^{50}$ Huang Ju, ${ }^{51} \mathrm{Jia}$ Qinglin ${ }^{52}$ and Zeng Qinghong ${ }^{53}$ publicly exhort various sections of the Party, government and society to work together to fight SARS. But the closing of party ranks does not necessarily mean that Hu's leadership of the Party has strengthened. It can only be 
surmised that Jiang's faction has chosen for the moment to work together to face a common threat. $\mathrm{Hu}$ will have to continue to tread carefully if he wants to consolidate power.

\section{Hu Jintao Remains Cautious}

$\mathrm{Hu}$ has been careful not to appear to upstage or be seen to be disrespectful of Jiang. Since he was elevated to the Politburo Standing Committee in 1992, Hu has assumed such a low profile that the foreign media has often portrayed him as a political enigma. ${ }^{54}$ Even after he was named the General Secretary, Hu pledged that on important matters he would seek instructions from and listen to the views of his predecessor. $^{55} \mathrm{Hu}$ has even stated that he will continue with Jiang's policies.

To be sure, $\mathrm{Hu}$ has consciously set out to establish his own distinctive leadership style, one that is more mass-oriented. But in terms of substance, $\mathrm{Hu}$ has essentially not deviated much from the policies and directions set by his predecessor. At a three-day symposium to mark the $82^{\text {nd }}$ Anniversary of the founding of the Party on July 1, 2003, Hu called on the Party and the whole nation to launch a new wave of study on the "Three Represents." that the SARS episode had provided an unprecedented opportunity for $\mathrm{Hu}$ to embark on political reforms in China, Hu completely avoided this topic in his speech.

Likewise at a Politburo meeting in August 2003, Hu stated that Deng Xiaoping theory and "Three Represents" should serve as guidelines for improving the socialist market economic system and revising China's Constitution, two key agenda items that would be discussed at the $3^{\text {rd }}$ Plenum of the $16^{\text {th }}$ Party Congress in October 2003. ${ }^{57} \mathrm{Hu}$ is meticulously toeing the line set by his predecessor.

Yet under the broad framework of the "Three Represents," $\mathrm{Hu}$ is subtly trying to introduce some of his own interpretations. For instance, in his address at the "Three Represents" symposium in July 2003, Hu said that the essence of the "Three Represents" theory was that the Party should be established for the interests of the public and govern in the people's interests (lidang weigong, zhizheng weimin). This marks a shift in the Party's orientation from Jiang's focus on the role that private entrepreneurs and capitalists could play in building socialism with Chinese characteristics to one that stresses on the importance of addressing the expectations and needs of the masses. It would be difficult for Hu's political opponents to fault him on this small innovation to Jiang's "Three Represents" theory. More of such innovations can be expected in the future given the theory's broad reference.

To a great degree, $\mathrm{Hu}$ is in a better position than Jiang when the latter was thrust into the limelight in 1989. Unlike Jiang, Hu has successfully weathered a 10year apprenticeship at the pinnacle of power. This is no mean achievement and is testimony to $\mathrm{Hu}$ 's intelligence, political astuteness and tenacity in the face of adversity. He can also tap on his network of supporters in the Communist Youth League, Qinghua University and Central Party School, but he is likely to do so without unduly alarming the other Politburo Standing Committee members whose support he needs. 


\section{CONCLUSION}

The outcomes of the $16^{\text {th }}$ Party Congress have provided some positive indication of the institutionalization of political succession in China. It is the first ever peaceful leadership transition. Also, the scale of change among the top leadership is unprecedented as characterized by the greater number of younger and better educated leaders at the helm.

These improvements, however, should be set in context as the conduct of politics in China is still very much based on the rule of man. At most, the institutionalization manifested at the Congress has somewhat conditioned the conduct of political succession but has not displaced the predominant yet informal nature of politics in China. This is obvious from Jiang's success in leaving his imprint on history by getting his "Three Represents" theory included in the Party's Constitution. Also, Jiang played an instrumental role in putting his men in positions of influence in the Party and government. ${ }^{58}$

$\mathrm{Hu}$ is now confronted with the challenge of consolidating power. In the initial years at least, $\mathrm{Hu}$ will have difficulty being his own man given the predominance of Jiang and his faction. In addition, there is Jiang's likely continued involvement in some key decision-making areas particularly on military affairs. Not only has $\mathrm{Hu}$ not secured Jiang's unequivocal support but he is hemmed in by Jiang's supporters in key party and government organizations. It is too early to speculate if $\mathrm{Hu}$ would be a one-term Party Secretary; but what is certain is that he would have to live with Jiang's presence for a while.

\section{Notes}

1 "Hu elected to top post," Beijing Review, December 5, 2002.

${ }^{2}$ The key point here is that the unprecedented leadership transition occurred under Jiang's watch. But whether Jiang consciously or unconsciously sought to achieve such an outcome is debatable.

${ }^{3}$ Frederick C. Teiwes, "Normal Politics with Chinese Characteristics," in The Nature of Chinese Politics, ed. Jonathan Unger (Armonk, New York: Sharpe, 2002), pp. 239-257. In Frederick Teiwes' view, "normal politics" most fundamentally means that politically leaders at the apex of a partially institutionalized system are beset with an enormous range of issues and pressures, without any dogmatic ideological compass to guide them. It means that leaders perform the function of aggregating diverse interests into a coherent, or not so coherent, program to satisfy various constituencies in order to maintain a policy thrust or to build support for an individual or a leadership group. Teiwes contends that unanticipated problems are the stuff of "normal politics".

${ }^{4}$ Tang Tsou, "Chinese Politics at the Top: Factionalism or Informal Politics? Balance-of-Power Politics or a Game to Win All?," in The Nature of Chinese Politics, ed. Jonathan Unger (Armonk, New York: Sharpe, 2002), p 102.

${ }^{5}$ Susan Shirk, "The Delayed Institutionalization of Leadership Politics," in The Nature of Chinese Politics, ed. Jonathan Unger (Armonk, New York: Sharpe, 2002), pp. 297-311. Even though Shirk contends in her article that China is at a low level of institutionalization in terms of political succession, she did add the caveat that if "Jiang Zemin, Li Peng, Zhu Rongji retire from all their positions during 2002-2003, it will indicate that institutionalization in Chinese leadership politics has finally taken hold".

${ }^{6}$ In a separate article on the $16^{\text {th }}$ Party Congress, Joseph Fewsmith has noted that although Hu was named general secretary of the CCP as expected, Jiang packed the Politburo and its Standing 
Committee with his allies and retained his position as head of the Party's Central Military Commission. In Fewsmith's view, although Hu may eventually assume real power, the outcome of the Congress made it clear that meaningful political succession remains at least five years away. In forcefully asserting his power, Jiang raised questions about the degree to which political governance, particularly at the very top, has been institutionalized. See Joseph Fewsmith, "The Sixteenth National Party Congress: The Succession that Didn't Happen," China Quarterly, Vol. 172, March 2003, pp. 116.

7 "Hu's in Charge," Time (Asia), November 25, 2002.

8 "Hu pledges to confer with Jiang on issues," International Herald Tribune, November 21, 2002.

9 "The Shanghai faction consolidates its grip on power," South China Morning Post, November 16, 2002.

10 "Is Hu going to be lame-duck leader?" The Sunday Times, November 17, 2002.

11 "Horse-trading for China's top political posts," Straits Times, August 3, 2001. See also "Princelings make their presence felt in China," Straits Times, December 14, 2002.

12 "Mr Fixit hits the ground running," South China Morning Post, May 7, 2003.

${ }^{13}$ Cheng Weigao also previously served as Governor and Secretary of Hebei Province in the 1990s. See "Disgraced official highlights chinks in system," China Daily, August 15, 2003 and "Dumped Hebei official facing corruption trial," Straits Times, August 11, 2003.

${ }^{14}$ The stress on ensuring a conducive environment for the Congress was not confined to the domestic arena. On foreign policy, the authorities continued to raise China's international profile and build relations with other countries while downplaying disputes. Most significantly, great efforts were made to stabilize China-US relations through high level exchanges of visits and the resumption of bilateral military ties. In his address to Qinghua University students during his visit to China in February 2002, Bush welcomed the emergence of a "strong, peaceful and prosperous China", a much more conciliatory tone compared to the start of his administration. Hu was virtually accorded Head-of-State treatment when he visited the US in April 2002. Jiang also met Bush at his Texas ranch in October 2002, an invitation extended only to close friends of the US President. China's relations with Taiwan were also put on a low key. China did not over-react when Chen Shui-bian described Taiwan's relations with China as "one country on each side" of the Taiwan Straits in August 2002. In November 2002, China further consolidated relations with its southern neighbors by signing a framework agreement with ASEAN to establish a China-ASEAN Free Trade Zone by 2010. 15 "Sanxia gongcheng daoliu mingqu jieliu shengli helong" (The successful damming of the three Georges Dam), Renmin Ribao, November 7, 2002.

16 "Kaichuang guoyou qiye dangjian gongzuo xinjumian" (Opening a new chapter in party building within the State-Owned Enterprises), Qiushi, April 16, 2002.

17 "Zhongyang yanfang wulei puohuai shili" (Party Central heightens vigilance against five types of destructive forces), Ming Bao, April 10, 2002.

18 "Zhongxuanbu ban chuanmei baodao sanshier jinji” (The Central Propaganda Department issues 32 taboos on media reporting), Ming Bao, June 21, 2002.

${ }^{19}$ The eight government bodies were the Ministry of Public Security, Ministry of Education, Ministry of State Security, Ministry of Information Industry, Ministry of Culture, State Administration for Industry and Commerce, State Council Information Office and State Bureau of Secrecy.

20 "Shiliudaqian yue shuaixian qingwang" (Before the $16^{\text {th }}$ Party Congress, Guangdong takes the lead to curb access to undesirable information on the Internet), Ming Bao, May 3, 2002. An attempt was also made to block access by locals to log on to the internationally renowned search engine Google but to no avail. It is widely believed that this move was prompted by Google's ability to lead Chinese users to sites considered undesirable by the authorities.

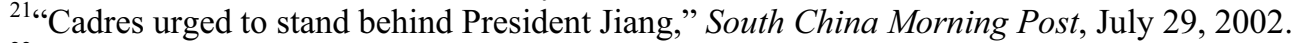

22 "Jianchi yi sangedaibiao wei zhidao quanmian tuijin junshi douzheng zhunbei" (Persist with "Three Represents" as the guiding principle to comprehensively push forward with preparations for military struggle), Jiefang Junbao, January 9, 2002 and see "Yi wusanyao zhongyao jianghua jingshen wei 
zhidao buduan tuidong junshi gongzuo xiang zongshen fazhan" (Using the important spirit of the May $31^{\text {st }}$ speech as the basis to continuously push ahead with the ever deepening military work), Jiefang Junbao, June 29, 2002.

23 "Shenru guanche wusanyao zhongyao jianghua jingshen jiji tuijin guofang he jundui jianshe" (Fully imbibe the important spirit of the May $31^{\text {st }}$ speech to push forward with defense and army construction), Jiefang Junbao, June 25, 2002.

24“"Jiang daju, jiang tuanjie, jiang wending" (Talk big picture, talk unity and talk stability), Renmin Ribao, July 22, 2002.

${ }^{25}$ Zeng Qinghong is well known as Jiang's most loyal lieutenants. When Jiang was consolidating power, Zeng played a crucial role in helping Jiang overcome his political opponents like the Yang brothers, Chen Xitong and Qiao Shi. At the $15^{\text {th }}$ Party Congress in 1997, Jiang succeeded in appointing Zeng as an alternate member of the Politburo and a full member of the Party Central Committee. Between the $15^{\text {th }}$ Party and $16^{\text {th }}$ Party Congress, Jiang had made a few attempts to elevate Zeng to become a full member of the Politburo but to no avail. Zeng remained as an alternate member of the Politburo till the $16^{\text {th }}$ Party Congress.

26،"Zhongyangzuzhibu zhongyangxuanchuanbu zhuyao fuze tongzhi zhiwu tiaozheng" (Reshuffling of portfolios of key comrades in the Central Organization Department and Central Propaganda Department), Renmin Ribao, October 25, 2002.

${ }^{27}$ The posts vacated by Jia Qinglin and Huang Ju were filled by Liu Qi and Chen Liangyu respectively, both of whom were politically acceptable to Jiang.

${ }^{28}$ In order to come up with a comprehensive report, the drafting committee collated inputs from relevant government departments and party organizations as well as conducted site visits to various provinces. As early as August 2001, these organizations formed 14 discussion groups to examine issues such as Party building, the overall situation in the country, the development of advanced productive forces and culture, and distribution of income. Hu chaired meetings to collate the views of these discussion groups. Also, the drafting committee formed eight groups to conduct site visits to 16 locations throughout the country including Guangdong, Jiangsu, Shanghai, Heilongjiang and Gansu. During the site visits, a total of 80 seminars were held involving 914 people. See http://news.xinhuanet.com/newscentre/2002-11/20/content_634795.htm for background to the drafting of the political report to the $16^{\text {th }}$ Party Congress.

29 "Quanmian guanche sangedaibiao yaoqiu yushijujin nuli kaichuan jianshe youzhongguoteseshehuizhuyishiye xinjumian" (Fully imbibe the requirements of the "Three Represents" to move with the times and work to open up and construct a new chapter in socialism with Chinese characteristics), Renmin Ribao, June 1, 2002.

30"Renzhen zhuahao 'tiaoli' de xuexi guanche buduan tigao ganbu xuanba renyong gongzuo shuiping" (Seriously study and imbibe the "regulation" to continuously raise the selection and appointment standards of cadres), Renmin Ribao, July 23, 2002.

31 "Hu calls on party officials to back President Jiang's political vision," South China Morning Post, September 3, 2002.

${ }^{32}$ Bao Tong wrote a 15 -page essay which was reviewed by The Wall Street Journal. An excerpt was reproduced in China's Unrepresentative Communists, Asian Wall Street Journal, August 28, 2002.

33 "Jiang encounters fierce criticism - liberals, conservatives attack social policies of the Chinese President," Asian Wall Street Journal, August 28, 2002.

${ }^{34}$ Deng mapped out a three-stage growth strategy in 1979 as part of his plan to kick-start China's moribund economy. The first step envisaged by Deng was the doubling of the 1980 GDP by the year 1990. The goal then was to achieve a state of wenbao or a state where the people were well-fed and clothed. The second step envisaged by Deng was a doubling of the 1990 GDP by 2000 . The goal was to achieve a well-off state or xiaokang. Deng's third step was to achieve full-scale modernization by 2050 although he did not spell out any targets.

35 "Quanmian jianshe xiaokangshehui de fendou mubiao" (The targets to achieve a comprehensive construction of a comfortable society), Renmin Ribao, November 9, 2002. According to Dr Li Jinwen, one of the drafters of China's $10^{\text {th }}$ Five Year Plan (2001-2005), this would mean achieving a GDP of 
around US $\$ 4$ trillion by 2020 with a per capital income of US\$3,100. See "Jiang maps out road to full modernization," The Sunday Times, November 10, 2002.

36 "Jiji tuijin guofang he jundui jianshe - renzhen guanche luoshi shiliuda jingshen" (Actively push forward with defence and army construction - seriously imbibe and fulfill the spirit of the $16^{\text {th }}$ Party Congress), Qiushi, December 1, 2002.

37 "Xinwen beijing: xiaotangshan yiyuan huifang" (Background News: Chronology of Xiaotangshan Hospital), Xinhuanet, June 20, 2003 (nttp://big5.xinhuanet.com/gate/big5/

news.xinhuanet.com/newscenter/2003-06/20/content 929286.htm). See also "Jiefangjun xiaotangshan yuan yuanzhang Zhang Yanling huigu xiaotangshan kangji feidian gongjianzhan" (The PLA Head of the Xiaotangshan Hospital Zhang Yanling recalls the uphill battle against SARS), Chinesenewsnet, July 29, 2003 (http://www1.chinesenewsnet.com/gb/MainNews/SocDigest/Health/072920031149L: 424299385.htm.)

38 "Jiang Zemin fa yandian aidao 361hao qianting yunan guanbin weiwen qinshu" (Jiang issues condolence message to the relatives of officers and soldiers of the 361 submarine mishap), Xinhua News Agency, May 2, 2003 (http://www.chinanews.com.cn/n/2003-05-02/26/299688.html). See also "Seventy crew killed in submarine accident," China Daily, May 3, 2003 and "Suffocation killed 70 on sub, says report," South China Morning Post, May 5, 2003.

${ }^{39}$ Front-page photos of Jiang have appeared in the following dailies: "Jiang Zemin shaking hands with the families and relatives of the victims of the Ming-class submarine mishap," Renmin Ribao, May 6, 2003; "Jiang Zemin and Hu Jintao meeting separately with Indian Prime Minister Shri Atal Bihari Vajpayee," Jiefang Ribao, June 25, 2003; "Jiang Zemin and Hu Jintao appearing at the wake of former Vice Premier, State Councilor and Defence Minister Zhang Aiping," Renmin Ribao, July 13, 2003; "Jiang Zemin leading members of the CMC to meet participants at the $14^{\text {th }}$ Work Conference of Military Officers," Renmin Ribao, July 21, 2002; and, "Jiang Zemin and Hu Jintao meeting separately with British Prime Minister Tony Blair," Jiefang Junbao, July 22, 2003;

40 "China: The New Leadership - A Power Crisis Looms," Far Eastern Economic Review, December 26, 2002.

41 "Hu Jintao visits revolutionary base," Xinhua News Agency, December 7, 2002. It was in Xibaipo, on the eve of the Party's victory over Chiang Kai-shek's regime, that Mao Zedong had urged each and every cadre to avoid complacency and preserve the revolutionary spirit of "plain and living struggle".

42،"Stable rural policy stressed by central conference," Xinhua News Agency, January 8, 2003. See also "Profile - Wen Jiabao, Premier of State Council (4),"Xinhua News Agency, March 15, 2003.

43"CPC leader calls on publicity officials to improve work," Xinhua News Agency, April 15, 2003. See also "Senior CPC leader calls for studies of $16^{\text {th }}$ CPC National Congress guidelines," Xinhua News Agency, February 12, 2003 and "Ranking CPC official underlines publicity work," Xinhua News Agency, January 8, 2003.

44 "Vice-President inspects newly-designated SARS patient reception hospital," Xinhua News Agency, April 30, 2003.

${ }^{45}$ They were both first stripped of their communist party posts on April 20, 2003 and subsequently removed from their official positions.

${ }^{46}$ In contrast, Zhang Wenkang was appointed Health Minister in 1998.

47 "Hu's political future may hinge on SARS," International Herald Tribune, April 25, 2003. See also "SARS battle puts new Chinese leader to the test," The New York Times, April 26, 2003 and "Pair sacked over handling of outbreak," South China Morning Post, April 21, 2003.

48 "CPC to launch new round of study of 'Three Represents' theory," Xinhua News Agency, April 28, 2003. "Yanjiu zai quandang xingqi xuexi guanche sangedaibiao zhongyao sixiang xingaochao deng gongzuo" (Study within the Party on reviving the learning and imbibing of the important thoughts of "Three Represents" to a new height and its related work), Renmin Ribao, April 29, 2003.

${ }^{49}$ It is no coincidence that the same Politburo meeting discussed how to handle the relationship between economic work and the fight against SARS. The meeting also called on all localities and departments to continuously move forward with economic work while going all out to combat SARS. 
${ }^{50}$ At the second meeting of the $10^{\text {th }}$ NPC Standing Committee on April 26, 2003, Wu Bangguo called on all lawmakers to work closely with the central government to fight SARS with the joint effort of all sectors. See "Wu Bangguo: ba xixiang he xingdong tongyi dao zhongyang de jingshen shanglai qixin xieli di zuohao feidianxingfeiyan fangzhi gongzuo" (Wu Bangguo: Combine thoughts and actions with the spirit held by the central and work wholeheartedly together to carry out SARS prevention work), Renmin Ribao, April 27, 2003.

${ }^{51}$ During an industrial tour in Beijing on May 2, 2003, Huang Ju stressed the importance of producing adequate SARS-related medical supplies and uninterrupted power supply to SARS-related hospitals and quarantined areas. See "Vice-Premier urges greater efforts to provide supplies for SARS fight," Xinhua News Agency, May 2, 2003. See also "Huang Ju: quanli yifu quebao gongying zhongzhi chengcheng kangji feidian" (Huang Ju: wholeheartedly ensure adequate supplies and strong public morale to curb SARS), Renmin Ribao, May 3, 2003.

${ }^{52}$ At a SARS workshop in Beijing on April 30, 2003, Jia Qinglin called for multi-party cooperation by urging non-communist parties and individuals to devote themselves to the anti-SARS campaign. See "Non-communist parties asked to help fight SARS," Xinhua News Agency, April 30, 2003. See also "Jia Qinglin: tongyi zhanxian yaowei duoqu kangji feidian douzheng de shengli xianji chuli" (Jia Qinglin: A united-front to ensure efforts towards a successful outcome in the battle against SARS), Renmin Ribao, May 1, 2003.

${ }^{53}$ When Zeng Qinghong visited the Sino-Japanese Hospital (a hospital designated to receive SARS patients) on April 30, 2003, he praised the medical staff that were at the front-line of the fight against SARS and urged Party members among the medical staff to play a leading role in the campaign. See "Vice-President inspects newly-designated SARS patient reception hospital," Xinhua News Agency, April 30, 2003. See also "CPC members urged to play a leading role in fighting SARS, boosting economy," Xinhua News Agency, May 21, 2003.

${ }^{54}$ The adjective "enigmatic" was used to describe Hu in an article in Far Eastern Economic Review. See "Hu was Here," Far Eastern Economic Review, May 16, 2002. See also "Cadre with the wrong background who always steered clear of trouble," South China Morning Post, April 22, 2002; "Meet $\mathrm{Mr} \mathrm{Hu}$ - or should it be Mr who?," Asian Wall Street Journal, April 30, 2002; “The Mystery - Who's Hu?," Straits Times, April 30, 2003; and, "Hu reveals little but gets what he wanted," Straits Times, May 4, 2002.

55 "Hu pledges to confer with Jiang on issues," International Herald Tribune, November 21, 2002.

See also "Hu speaks softly for quiet reform," Asian Wall Street Journal, November 18, 2002.

56 "Hu Jintao zai yantaohui zuo zhongyao tanhua: zhenxin xue sangedaibiao lidang weigong zhizheng weimin shi biaozhi" (Hu's important speech at the symposium: whole-heartedly study the "Three Represents", follow the guidelines of establishing the Party for the interests of the public and governing in the people's interests), Xinhuanet, July 1, 2003. See also "Hu Jintao urges greater effort in implementing the 'Three Represents' (1)," Xinhua News Agency, July 1, 2003.

57 "Shiliujie sanzhong quanhui shiyue zhaokai" (The $3^{\text {rd }}$ Plenum of the $16^{\text {th }}$ Party Congress will convene in October), Xinhuanet, August 11, 2003. See also "Sanzhong quanhui taolun jinggai xiuxian" (The $3^{\text {rd }}$ Plenum will discuss economic reforms and amendments to the Constitution), Ming Bao, August 12, 2003 and "October Party Meeting focuses on amending Constitution," China Daily, August 12, 2003.

${ }^{58}$ At the $10^{\text {th }}$ NPC in March 2003, a couple of Jiang's men secured key positions in the government. Among his key supporters, Zeng Qinghong is Vice President; Wu Bangguo is Chairman of the National People's Congress; Huang Ju is Vice Premier; Zeng Peiyan is also Vice Premier; Jia Qinglin is Chairman of the Chinese People's Political Consultative Committee; Chen Zhili is State Councilor and Zhou Yongkang is Minister of Public Security. Zhou's appointment marks the first time a Politburo member has been made public security minister since the end of the Cultural Revolution. 